\title{
Performance of the tariff method and physicians in determining stroke as the cause of deaths using verbal autopsy in areas with a limited number of physicians: cases in Indonesia
}

DOI: https://doi.org/10.22435/hsji.v12i1.4805

Endang Indriasih, ${ }^{1}$ Meiwita P Budiharsana ${ }^{2}$

${ }^{1}$ National Institute of Health Research and Development, Ministry of Health, Republic of Indonesia

${ }^{2}$ Faculty of Public Health, University of Indonesia

Corresponding author: Dr. Endang Indriasih, SKM., M.Si

Email: e_indriasih@yahoo.com

Received: April 22, 2021; Revised: May 31, 2021; Accepted: June 11, 2021.

\begin{abstract}
Background: Physician-certified verbal autopsy (PCVA) is the primary method used to determine the cause of death in Indonesia, although it is very costly and problematic to use in areas where physicians are not widely available with most deaths occur at home. The Tariff method has been piloted to obtain an alternative approach that does not require a physician to determine the cause of death. This validation study presents how the Tariff captures the correctness and distinctiveness of stroke symptoms to the PCVA.

Methods: Medical records of 298 adult deaths that occured in four teaching hospitals in the Jakarta from January 1, 2015 to March 2017 were collected prospectively. Verbal Autopsy (VA) was applied using the 2014 WHO instrument diagnosed by a trained physician (PCVA) and by Tariff method. The validity of the VA was assessed by comparing the PCVA diagnoses with the Tariff diagnoses, referring to the best standard.

Results: Sensitivity, specificity and positive predictive value (PPV) of VAs using physician's diagnosis (PCVA) for stroke were $73.9 \%, 73.5 \%$ and $93.4 \%$ respectively. The corresponding sensitivity, specificity and positive predictive value (PPV) of VAs diagnosed by the Tariff method were $75 \%, 61 \%$ and $91 \%$. The negative predictive values (NPV) of both techniques were low, 35.6\% and 32.6\% respectively.

Conclusion: The performance of the Tariff method for stroke was almost similar with PCVA, and with a narrower variation, or more consistent than PCVA. Therefore, the Tariff method is a potential alternative to be used on a large scale, because the difficult geographical conditions where physician are not widely available for causes of deaths with distinct signs and symptoms. (Health Science Journal of Indonesia 2021;12(1):39-46)
\end{abstract}

Keywords: verbal autopsy, sensitivity, specificity, determining cause of death, physician, tariff method

\begin{abstract}
Abstrak
Latar Belakang: Autopsi verbal yang disertifikasi oleh dokter (PCVA) merupakan metode utama yang digunakan untuk memastikan penyebab kematian di Indonesia. Meskipun sangat mahal dan bermasalah untuk digunakan di daerah di mana dokter tidak banyak tersedia dan sebagian besar kematian terjadi di rumah. Metode Tarif telah diujicobakan untuk mendapatkan pendekatan alternatifyang tidak memerlukan dokter untuk menentukan penyebab kematian. Studi validasi ini menyajikan bagaimana Tarif menangkap kebenaran dan kekhasan gejala stroke dibandingkan dengan PCVA.
\end{abstract}

Metode: Rekam medis dari 298 kematian orang dewasa yang terjadi di empat rumah sakit studi di wilayah Jakarta pada 1 Januari 2015 hingga Maret 2017 dikumpulkan secara prospektif. Autopsi verbal (AV) dilakukan dengan menggunakan instrumen WHO 2014 yang didiagnosis oleh dokter terlatih (PCVA) dan metode Tarif. Validitas AV dinilai dengan membandingkan diagnosis PCVA dengan diagnosis metode Tarif, mengacu pada baku mutu.

Hasil: Sensitivitas, spesifisitas dan nilai prediksi positif (PPV) dari AV dengan diagnosis dokter (PCVA) untuk stroke adalah 73,9\%, 73,5\% dan 93,4\%. Sensitivitas, spesifisitas, dan nilai prediksi positif (PPV) yang sesuai dari AV yang didiagnosis dengan metode Tariff adalah 75\%, 61\% dan 91\%. Nilai prediksi negatif (NPV) dari kedua teknik itu rendah, masing-masing 35,6\% dan 32,6\%. 


\begin{abstract}
Kesimpulan: Untuk stroke, kinerja metode Tarif hampir sama dengan PCVA, dan dengan variasi yang lebih sempit, atau lebih konsisten dibandingkan PCVA. Oleh karena itu, untuk penyebab kematian dengan tanda dan gejala yang berbeda, metode Tarif merupakan alternatif potensial untuk digunakan dalam skala besar, di Indonesia dimana banyak wilayah dengan geografis sulit dan dokter tidak selalu tersedia. (Health Science Journal of Indonesia 2021;12(1):39-46)
\end{abstract}

Kata kunci: autopsi verbal, sensitifitas, spesifisitas, penentuan penyebab kematian, dokter, metode tariff

As a developing country, Indonesia has not fulfilled the WHO's minimum threshold of 23 physicians, nurses and midwives per 10000 population. ${ }^{1}$ To makes it worse, Indonesia's Civil Registration and Vital Statistics (CRVS) system is still in the process of being developed making to provide timely vital statistics, complete and accurate. Located between two continents, Asia and Australia, Indonesia consists of eight large islands and nearly 17,000 small islands stretching more than 5,000 kilometers from Sabang in northern Sumatra to Merauke in Papua. This geographical difficulty has direct negative consequences on the deployment of physicians and other type of health workers in remote areas. Indonesia's governments need to obtain reliable cause of death statistics from various parts of the country including areas without physician, to inform public health policy, respond to emerging health needs, and document progress towards Sustainable Development Goals (SDGs). Therefore, data is collected using the electronic questionnaires on mobile devices and computer algorithms to responses analyzing and estimate the probability causes of death have increased the potential of ComputerCertified Verbal Autopsy method such as Tariff, to be an alternative method to determine cause of death.

Researchers at the Institute for Health Metrics and Evaluation (IHME) develop the Tariff method with an algorithm approach to symptoms or symptoms are recorded in the verbal autopsy instrument. The Tariff method is transparent, intuitive, flexible and at more cost less than PCVA. ${ }^{2}$ This application can be downloaded for free through the IHME website. ${ }^{2}$ The National Institute for Health Research and Development (NIHRD) has been using this application since 2015 for system activities recording deaths in several areas such as South Kalimantan, Bali and West Nusa Tenggara (NTB). ${ }^{3}$ The result showed that the officers at the Health Centre and the District Health Office were able to execute verbal autopsy (VA) using the computerized Tariff method. However, a study for validation of the method to determine cause of death using the Tariff method has never been carried out in Indonesia.

This study presents the strength and specificity of the tariff method to capture stroke symptoms that compared between PCVA and best standard for the method. Stroke is selected cases for point of interest in the validation test, because stroke was the highest cause of death $(21.1 \%)$ at Indonesia in $2014 .{ }^{4,5}$ The result of validation for the two methods in cause of death determining, will be valuable in to appropriate method regarding geographical condition and the limited number of physicians in Indonesia.

\section{METHODS}

This study used secondary data from the "Validation study of determining the cause of death in stroke cases with a physician-certified verbal autopsy and a computer-certified verbal autopsy- tariff method compared to the gold standard'. ${ }^{6}$ This study using a cross-sectional design, where sample selection was done purposively in two stages. The first stage is the selection of hospitals as research sample based on the number of deaths due to stroke reported to the DKI Jakarta Provincial Death Surveillance System. Four hospitals were selected in which two hospitals were tertiary hospitals and the rest were secondary hospitals, which all of them were equipped with CT scan facility, and three out of four are teaching hospitals. The second stage is the selection from causes of death in the selected hospital using the death surveillance list and the date when the event happened between January 1st 2015 - March 2017. The measurement for the stroke sample candidate is the death caused by stroke (based on the death surveillance record). The non-stroke sample was chosen if there is no stroke cases was recorded on the death surveillance. All samples were attached by searching their medical records at the sample hospitals, before doing home visit for a verbal autopsy interviews then. 


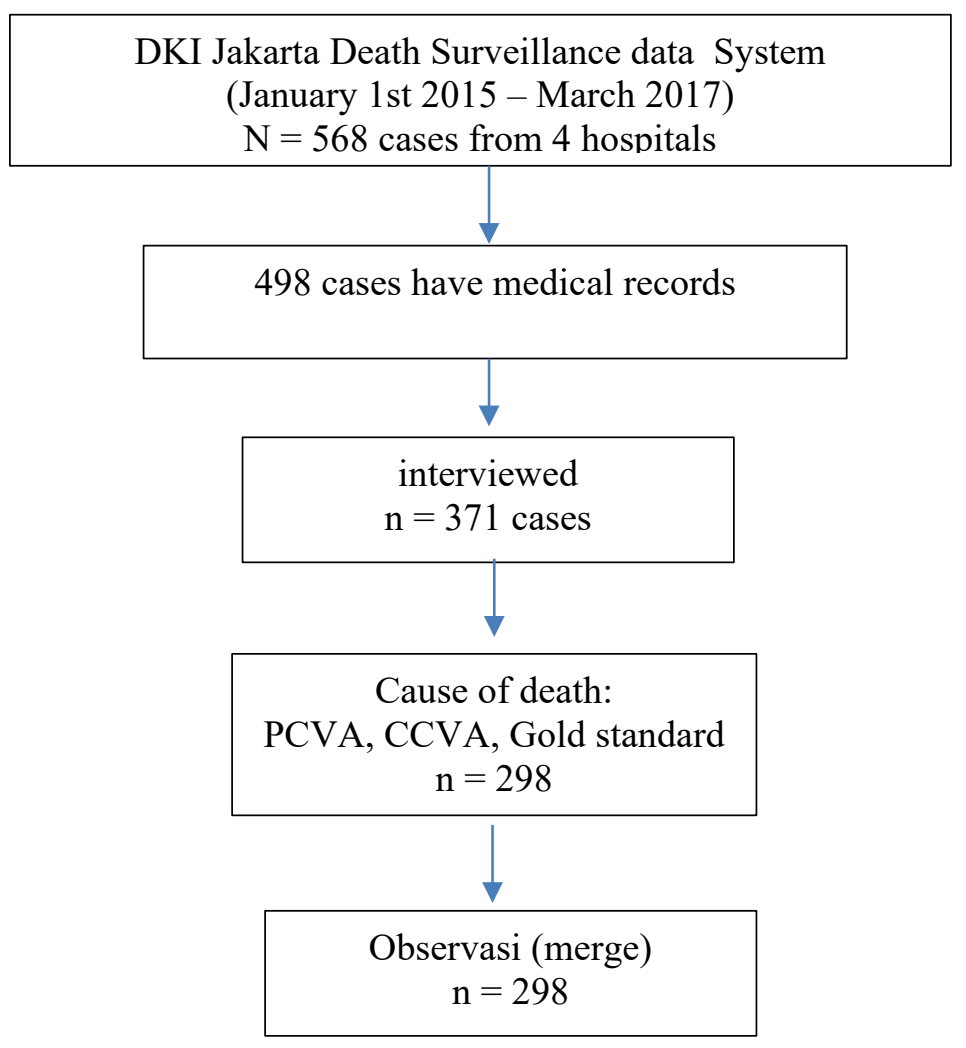

Figure 1. Data collection flow

270 cases did not full filled the inclusion of criterias, therefore were not included for further analysis. From 270 cases, $27 \%$ of cases were not verified because the un-retrieveable medical records (RM). There are exception for cases who also excluded because deceased's family had moved or not living in the same place $(30.7 \%)$, and family refused (7.4\%). Name of the deceased did not stay at the address as recorded in the medical record (28.9\%) or the Tariff method could not determine the cause of death (undetermined cases) (5.9\%). Interviews with the deceased family doing through with visited who made by trained interviewers using VA instruments, based on the death surveillance data, and every interviewers are graduates from public health and midwife academies. We used paper-based 2014 WHO VA instrument for adults ${ }^{7}$ with additional stroke signs of vertigo, slanted lips and aphasia. Interviews were held only to witnesses, friends, or family that were assumed to know the stroke symptoms or earlier signs prior to the death.

In the begining, interviews were conducted two times by two trainned enumerators. First enumerator interviewed with the WHO instrument and the second enumerator interviewed with PHMRC instruments. As a matter of fact, many of the deceased families were unable for two time interviewed. Most of the interviews were conducted only by using WHO instrument since PHMRC instrument's questions were also covered in WHO instrument.

\section{The gold standard}

The gold standard to determine the underlying cause of death follows the procedure established by the Population Health Metrics Research Consortium (PHMRC). ${ }^{8}$ Each medical record is reviewed by 2 to 3 physicians to determine the cause of death and it will be come the gold standard. Death caused by stroke was determined by these following clinical diagnosis criteria:

\section{Stroke (A)}

Level 1 Cases were confirmed by:

- A Computed Tomography (CT) scan or Magnetic Resonance Imaging (MRI);

- Sudden onset of paralysis, coma

Level 2A Within the 28 days prior to death, rapidly developing signs of a focal or global loss of cerebral function lasting more than 24 hours (or leading to death) with no apparent cause other than that of vascular origin 
Then the same medical records were reviewed by two trained and experienced physicians to determine certified cause of death, and if both physicians were concluded the same results, the cause of death was categorized as the cause of death at gold standard. If the result is disparate, the two physicians would have discussions to agree about the causes of death. If there is no agreement for the result, that case was reconciled to the third physician, until it would be used as the gold standard. The cause of death was coded according to the mortality tabulation, classified as a stroke or non-stroke case.

\section{Physician-certified verbal autopsy}

Every case of VA was reviewed by a general practitioner who has previous VA training on cause of death determination using ICD-10 codes, and in accordance to the WHO instrument method (without using algorithms), to determine the direct cause, antecedent causes and underlying causes. ${ }^{6,9}$

\section{Tariff method-computer-certified verbal autopsy}

Tariff method in this study were conducted using using Smart VA version-1.2.0 (published May 2017). Data were inputted using PHMRC shortened instrument developed by PHMRC, IHME, Washington University, consisted of 143 questions includes both closed-ended questions and an open-ended narrative. Based on the response pattern in the VA instrument, the Tariffs subsequently summed and yielding an item-specific Tariff score for each death for each cause. The cause that claims the highest Tariff score for a particular death is assigned as the predicted cause of death for that individual. The tariffs, scores, and ranks are easily observable at each step, and users can easily inspect the basis for any cause decision. ${ }^{2,10}$

\section{Analysis and data management}

The physician is supposed to be able for determine from one to four causes of death, while the Tariff method could determine only one cause of death. We decide to choose for only physician's underlying cause of death to undergo a validation test, defined by 2 categories: the stroke (stroke reffer to ICD-10: I60-I69) and non-stroke. Validity test is held by measuring sensitivity, specificity, positive predictive value of the cause of death determined by physicians and Tariff computerized method.

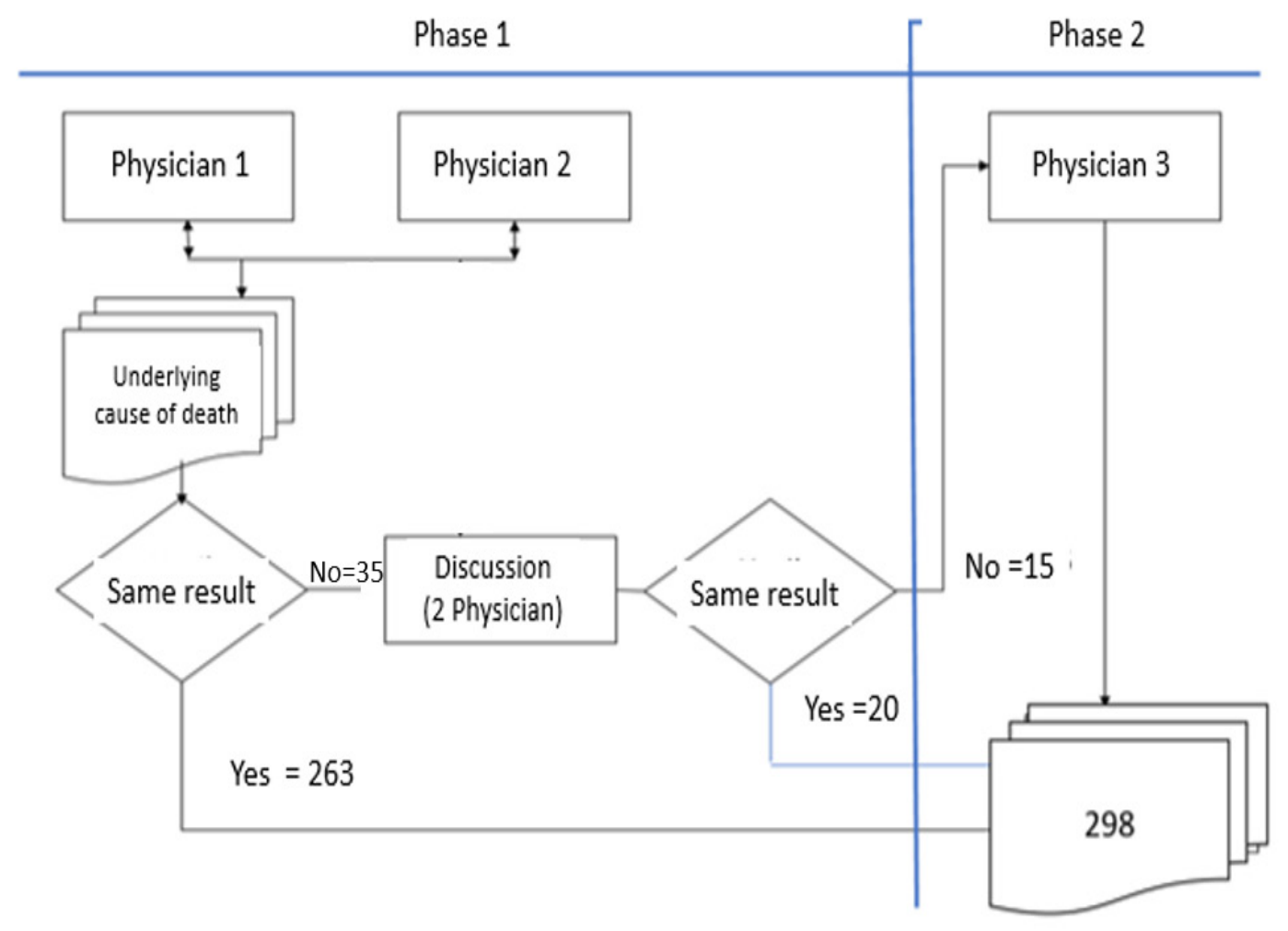

Figure 2. The gold standard mechanism of cause of death 
The formulas for this calculation were defined as:

Sensitivity $=\mathrm{TP} /(\mathrm{TP}+\mathrm{FN})$;

Specificity $=\mathrm{TN} /(\mathrm{FP}+\mathrm{TN})$;

Positive Predictive Value or PPV $=\mathrm{TP} /(\mathrm{TP}+\mathrm{FP})$;

Negative Predictive Value or NPV $=\mathrm{TN} /(\mathrm{FN}+\mathrm{TN})$

Where $\mathrm{TP}=$ true positive, $\mathrm{FP}=$ false positive,

$\mathrm{TN}=$ true negative, $\mathrm{FN}=$ false negative.

All analyses were carried out using Stata 10.

\section{Ethical Declaration}

This study had been approved by The Research and Community Engagement Ethics Committee Faculty of Public Health University of Indonesia with a letter number: 90/UN2.F10/PPM.00.02/2016.

\section{RESULTS}

The average time of interview for each case was approximately 30 minutes, where VA interview with the deceased family of these 298 cases was held after 1-27 months of death. There were $26,8 \%$ cases after 0-6 months, $24,2 \%$ after $7-12$ months, $27,5 \%$ after $13-18$ months and $21,5 \%$ more than 18 months after the events. However, the results of statistical tests between different interview period and the accuracy of physiscians or the Tariff method in determining the cause of death are not significant $(\mathrm{P}$ value $=0,370$ and P.value $=0,317$ ). About $49 \%$ respondents are children of the deceased, and $31.2 \%$ are the spouses. Age range for the deceased was 16-91years old (mean: 61 years old) old and 56\% of them is male.
The cause of death was determined based on positive response on symptoms or signs that found on the deceased. The highest response on stroke cases (PCVA) was 'loss of consciousness more than 24 hours' (66\%). Most of loss of consciousness occurred all of a sudden (73\%) and continued up to the death time $(91.6 \%)$ ). Positive response on 'paralysis' was about $63 \%$ cases, out of these $73 \%$ experienced hemiparesis (paralyzed on one side of the body). Vertigo was mentioned by $15 \%$ cases, asymmetrical lips (19\%) and aphasia (27\%). The medical record of the deceased (stroke patients) unraveled that: $69 \%$ had ever suffered from stroke, $77.2 \%$ ever suffered from hypertension, $23.5 \%$ ever suffered from a heart disease and $21.3 \%$ ever suffered from diabetes mellitus.

The result of all three cause of death methods (gold standard, PCVA and Tariff method) confirms that the major cause of death was stroke (84\%) (ICD-10: I60-I69), followed by diabetes mellitus and ischemic heart disease (see Figure 3).

Table 1 shows the distribution of cases, of the 298 deaths, the stroke established as the cause of death by gold standard criterion in 249 cases. About 149 stroke diagnoses (out of 249) were established using CT scan results combined with clinical symptoms recorded on the medical record (level 1), while on the other 100 stroke cases diagnoses were determined without any CT Scan results (level 2a) but based on medical record notes on a loss or change of global and/or vocal cerebral function occurred 28 days before death. Total diagnoses made through PCVA were 198 stroke cases, while through the Tariff method or SmartVA were 206 stroke cases.

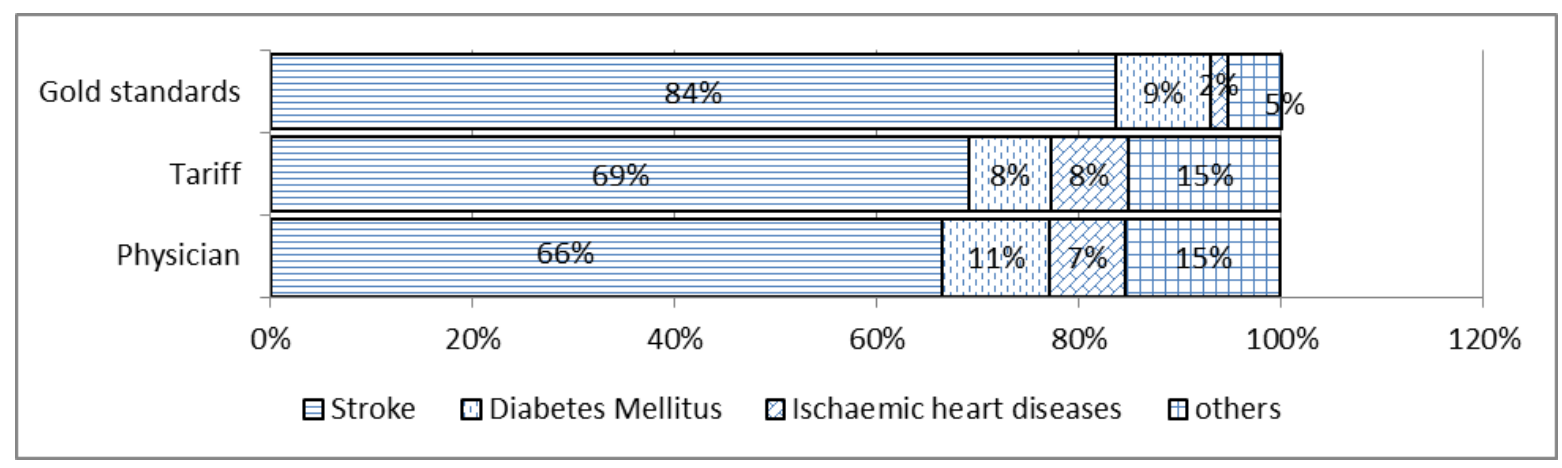

Figure 3. Variation in the proportion of each cause of death by methods 
Tabel 1. Distribution of cases

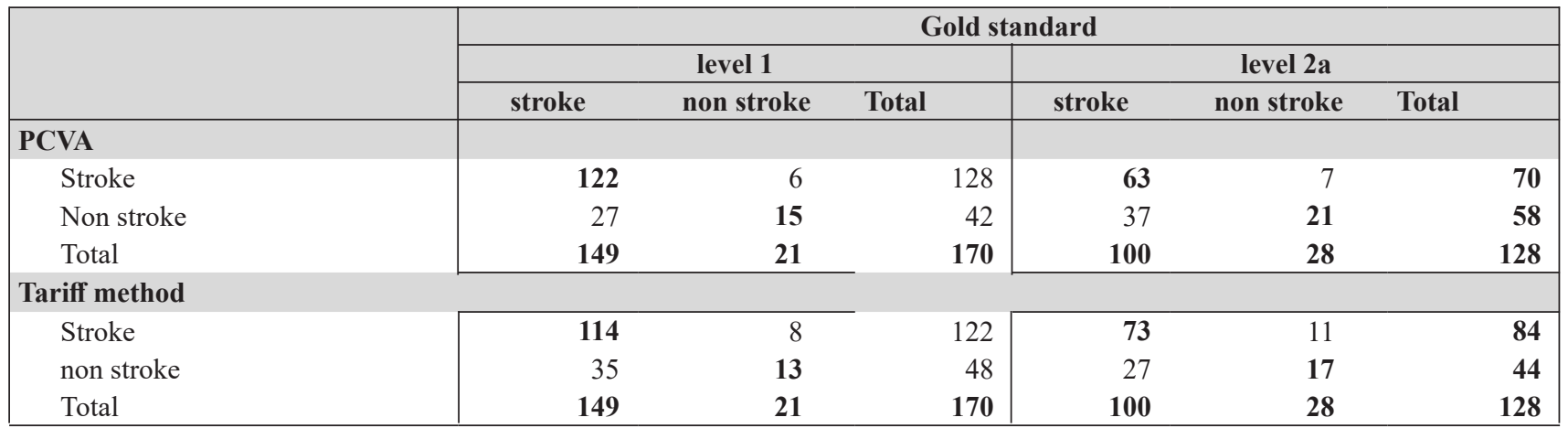

Source : Indriasih E. ${ }^{6}$

Table 2 shows similar level of ability between PCVA and Tariff method in determining stroke as the cause of death in general, with sensitivity for PCVA at 74.3\% (CI 95\%: 68.4-79.6) and for Tariff method at $75.1 \%$ (CI 95\%: 69.2-80.3). In comparison to the gold standard level (for 149 death cases) where diagnoses were established with CT Scan (level 1), the PCVA's prediction was better than tariff computerized method. While for the other 100 cases without CT Scan (level 2A), merely based on a written record about the loss or change of focal and/ or global cerebral functions in the medical record within 28 days before the death, the prediction ability of PCVA was lower than the prediction ability of Tariff computerized method.

Table 2. Differences in prediction ability of PCVA and Tariff method in determining stroke as the cause of death, compared to gold standard clinical diagnosis

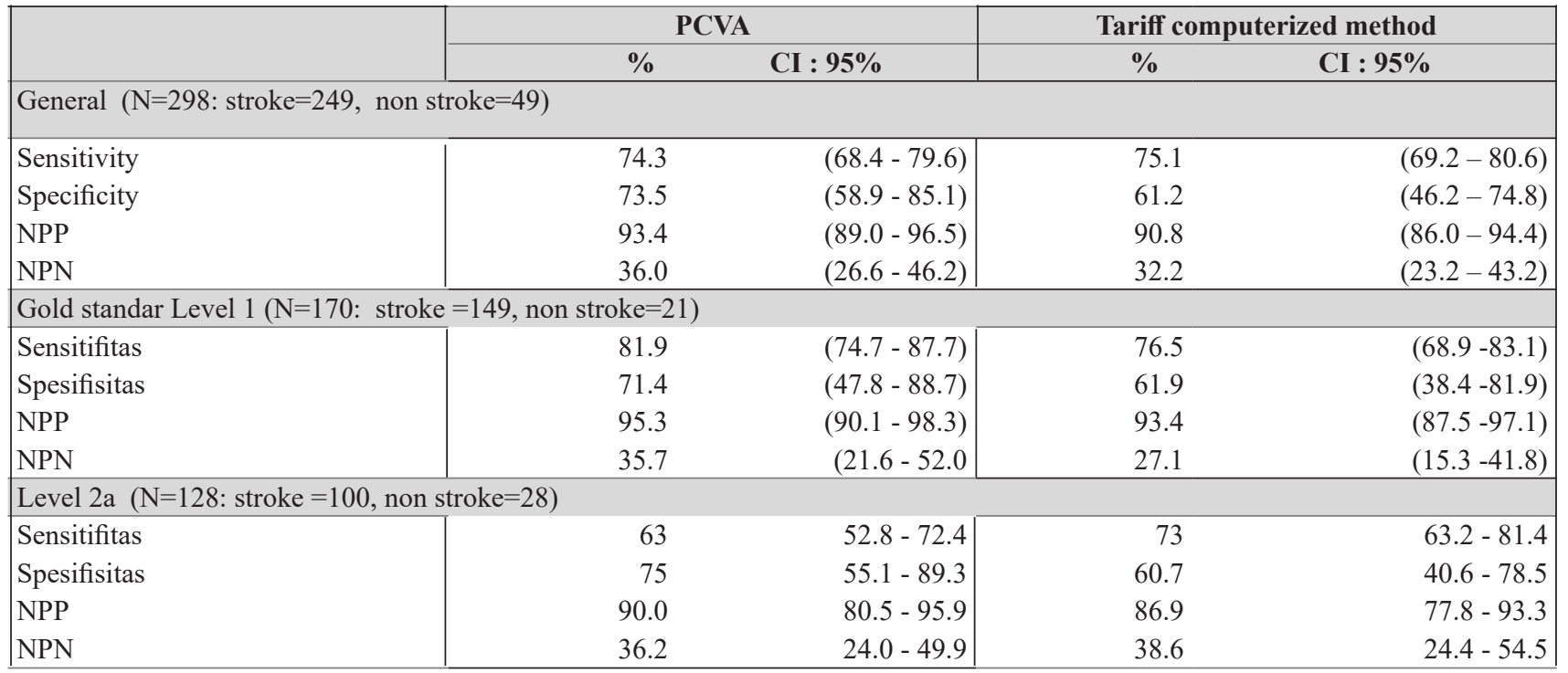

Source : Indriasih E. ${ }^{6}$

\section{DISCUSSION}

The findings indicate that both PCVA and Tariff method have similar performance in determining stroke as the cause of death. This study yields a higher sensitivity in determining stroke as cause of death compared to similar research conducted by IHME. ${ }^{11}$ Even when compared with the gold standard diagnoses that were made with $\mathrm{CT}$ scan result (level 1), the sensitivity result is still higher than the IHME study. The PCVA sensitivity result is closer to validation studies conducted in North India $(75 \%)$ and China $(81.5 \%){ }^{12,13}$ It is assumed that higher level of gold standard (with CT scan) would be reflected in a better prediction of PCVA, but there is no effect on Tariff computerized method's performance. Because, even when family members were informed by the hospital about CT 
Scan results that indicated a stroke had occurred, or other supporting diagnostic records were written in the medical record to confirm the occurrence of stroke, this additional information would just enrich the VA WHO instrument, but would not be useful for the Tariff PHMRC instrument. This situation makes PCVA performance (sensitivity level) better than Tariff's. Another possibility is that there are different procedures for determining the cause of death between cases. Ideally determine the cause of death based on all information obtained through VA interviews. This information can be provided from open, closed and open questions with narrative answers. There was a possibility that the physician more interested in reading narrative answers than closed answers, because diagnostic support information was in open answers and narration (free text). On the other hand, the gold level standard does not affect the results of determining the cause of death by the computer method of tariff, the possibility is that the consistency of the procedure is maintained with the algorithm.

In addition, a physician's text book knowledge and clinical experience also influence the variation of results (causes of death). While the Tariff score calculation is not influenced by physician's knowledge at all. In this study, the findings showed more cases of Gold Standard Level 1 ( $\mathrm{N}=170$ : stroke $=149$, non-stroke $=21$ ), because the hospitals involved are tertiary and secondary level hospitals with CT scan units in Jakarta, the capital of Indonesia. In a larger scale or national level, it should be anticipated that we will see more Gold Standard Level 2a, because lack of hospitals with CT Scan units outside of Jakarta, especially in remote areas, borders and islands of Indonesia. In such difficult geographical condition, around $70 \%$ of mortality occur outside of the hospital, and many of these areas have no physicians available.

At present PCVA assessment is not implemented as regular routine program for vital statistics in Indonesia, eventhough PCVA was well known on limited research projects or verbal autopsy studies such as SRS or CRVS. ${ }^{3,14}$ Thus, not all physicians can determine the cause of death using a verbal autopsy. Recent VA study which involving large scale of cases and spread out at 30 provinces was conducted by NIHRD in 2014. ${ }^{5}$ PCVA training would need many factors to consider such as resources (financial, qualified trainer, efficient method, etc) and also other important factors after training. According to NIHRD experience, PCVA training was held for 3 days. In fact, only few cases were discussed during training period and the physician need more practice especially for spesific cases. Thus, after the training should be followed by evaluation and monitoring which can be facilitated in a networking at first period of PCVA practiced at Puskesmas. Recently there are more than 10.000 Puskesmas in Indonesia ${ }^{15}$, then should be carefully considered if the training will be applied for all Puskesmas since the resources are limited and variation of cases might occurs in wide areas. That might occurs with the distribution of cases and large areas.

In a way, the findings pointed out that Tariff method which calculates a score, or "tariff" for each cause, for each sign/symptom, across a pool of validated verbal autopsy data presented a more reliable response pattern in a verbal autopsy compared to PCVA, which varied according to physician's knowledge, experience, CT Scan results, and supporting notes on additional symptoms within the last 28 days in the VA instrument. In addition, the use of the latest Tariff method version, results show a high sensitivity of $75.1 \%$, which is higher than the previous IHME study results of $51.8 \% .^{11}$

In conclusion, based on the results, verbal autopsies using Tariff method have similar performance level with PCVA in diagnosing stroke as the cause of death. Verbal autopsies for stroke cases using Tariff method were feasible for Indonesia which has many difficult geographical areas and lack of physicians in remote, border and islands areas. Lack of physicians is not a barrier anymore if Indonesia uses the tariff method in the implementation of VA. The Tariff method is proven to be reliable, transparent and flexible and can be readily implemented by users without training in statistics or computer science. This validation study provides scientific evidence that Tariff method has adequate validity level, as high as PCVA and the gold standard, and in areas where there is no physician.

\section{Acknowledgements}

The authors would like to thank Soewarta Kosen, Alan D Lopez, Abraham D. Flaxman (IHME), Indang Trihandini, Trihono, Budi Riyanto Wreksoatmodjo, Pungkas Bahjuri Ali, Besral, Ratna Djuwita for intelectual contribution to this study. This work was funded by Ministry of Health National Institute of Health Research and Development (NIHRD) and the University of Melbourne.

\section{Authors' contributions}

EI, conceptualized the framework. EI performed the PCVA method and Tariff algorithm in the field, under 
the supervision of SK. EI drafted the manuscript in Bahasa and MB helped write the manuscript in English. EI accepts full responsibility for the work and the conduct of the study, had access to the data, and controlled the decision to publish. EI and MB are the corresponding authors. All authors have read and approved the final English manuscript.

\section{Competing interests}

The authors declare that none of them have any competing interests.

\section{REFERENCES}

1. WHO. Achieving the health-related MDGs. It takes a workforce! [Internet]. WHO. 2018 [cited 2018 Apr 3]. Available from: http://www.who.int/hrh/ workforce_mdgs/en/

2. James SL, Flaxman AD, Murray CJ. Performance of the tariff method: validation of a simple additive algorithm for analysis of verbal autopsies[Internet]. Popul Health Metr. 2011;9(1):31. [cited 2018 Apr 3]. Available from: https://link.springer.com/ article/10.1186/1478-7954-9-31

3. Lusiana M. Laporan: riset implementasi sistem pencatatan sipil dan statistik hayati (PS2H)/CRVS. Jakarta; 2017. Indonesian.

4. WHO. World Health Statistics 2017 : monitoring health for the SDGs [Internet]. World Health Organization. 2017. 103 p. [cited 2018 Apr 3]. Available from: https://apps.who.int/iris/handle/10665/255336

5. Balitbangkes. Indonesia: sample registration system 2014. Kosen S, editor. Jakarta: Badan Penelitian dan Pengembangan Kesehatan; 2015. Indonesian.

6. Indriasih E. Disertasi: studi validasi penentuan penyebab kematian karena stroke dengan metode autopsi verbal oleh dokter dan komputer metode tariff dibandingkan dengan baku mutu. University of Indonesia; 2018. Indonesian.

7. WHO. Verbal autopsy standards: the 2014 WHO verbal autopsy instrument [Internet]. World Health Organization; 2014. 21 p. [cited 2015 Nov 22]. Available from: https://www.who.int/healthinfo/ statistics/verbalautopsystandards/en/
8. Murray CJ, Lopez AD, Black R, Ahuja R, Ali SM, Baqui A, et al. Population health metrics research consortium gold standard verbal autopsy validation study: design, implementation, and development of analysis datasets[Internet]. Popul Health Metr. 2011;9(1):27. [cited 2017 Apr 3]. Available from: https://pophealthmetrics. biomedcentral.com/track/pdf/10.1186/1478-7954-9-27

9. World Health Organization. ICD-10 : international statistical classification of diseases and related health problems (Volume 2) [Internet]. 2nd ed. Geneva: World Health Organization; 2005. [cited 15 November 2017]. Available from: https://www.who.int/ classifications/icd/ICD-10_2nd_ed_volume2.pdf

10. Serina P, Riley I, Stewart A, James SL, Flaxman AD, Lozano R, et al. Improving performance of the tariff method for assigning causes of death to verbal autopsies [Internet]. BMC Med. 2015 [cited 2017 Apr 3]. Available from: http://dx.doi.org/10.1186/s12916-015-0527-9.

11. Murray CJ, Lozano R, Flaxman AD, PS, Phillips D, JS, et al. Using verbal autopsy to measure causes of death: the comparative performance of existing methods [Internet]. BMC Med. 2014;12(1) [cited 2018 May 3]. Available from: https://link.springer. com/article/10.1186/1741-7015-12-5.

12. Yang G, Rao C, Ma J, Wang L, Wan X, Dubrovsky G, etal. Validation of verbal autopsy procedures for adult deaths in China [Internet]. Int J Epidemiol. 2006;35(3):741-8 [cited 2017 Apr 3]. Available from: https://academic.oup. com/ije/article/35/3/741/735507?login=true, ,

13. Gajalakshmi V, Peto R. Commentary: verbal autopsy procedure for adult deaths [Internet]. Int J Epidemiol. 2006;35(3):748-50. [cited 2017 Apr 3]. Available from: https://academic.oup.com/ije/ article/35/3/748/735910.

14. Indriasih E, Rosita $T$, Yulianti A, Agustiya RI. Penilaian kualitas data penyebab kematian di Indonesia Tahun 2014 [Internet]. Bull Penelit Kesehat. 2020;48(4):235-42 [cited 2021 Feb 3]. Available from: https://ejournal2.litbang.kemkes. go.id/index.php/bpk/article/view/3524. Indonesian.

15. Kementerian Kesehatan. Profil Kesehatan Indonesia Tahun 2019 [Internet]. Hardhana B, Sibuea F, Widiantini W, editors. Jakarta: Kementerian Kesehatan; 2020. [cited 2021 Apr 3]. Available from: https://pusdatin.kemkes. go.id/resources/download/pusdatin/profil-kesehatanindonesia/Profil-Kesehatan-indonesia-2019.pdf. Indonesian. 